\title{
Religion and the Study of Peace: Practice without Reflection
}

\author{
Atalia Omer
}

check for

updates

Citation: Omer, Atalia. 2021 Religion and the Study of Peace: Practice without Reflection. Religions 12: 1069. https://doi.org/10.3390/ rel12121069

Academic Editors: Gladys Ganiel and Joram Tarusarira

Received: 9 November 2021

Accepted: 26 November 2021

Published: 3 December 2021

Publisher's Note: MDPI stays neutral with regard to jurisdictional claims in published maps and institutional affiliations.

Copyright: (C) 2021 by the author. Licensee MDPI, Basel, Switzerland. This article is an open access article distributed under the terms and conditions of the Creative Commons Attribution (CC BY) license (https:// creativecommons.org/licenses/by/ $4.0 /)$.
The Kroc Institute for International Peace Studies, Keough School of Global Affairs, University of Notre Dame, Notre Dame, IN 46556, USA; aomer1@nd.edu

\begin{abstract}
Religion can be good and bad. For too long, the field of religion and peace has repeated this argument, cogently articulated by R. Scott Appleby in his field shaping The Ambivalence of the Sacred. It is time to examine whether there are other arguments to be made. The field of religion and peace is multifaceted and has grown exponentially in recent decades, primarily by enhancing various sites of policy making to mobilize "good" religion more effectively for its utility while devising more complex mechanisms to contain "bad" religion. This is not a bad development in and of itself and many actors populating the religion and peace spaces of practice do a lot of good in the world. However, without also subjecting the field to critique of its basic operative categories of analysis, the field in its various nodes will remain just that: practice, without reflection to recall Paolo Freire's critical pedagogical approach to transforming the world.
\end{abstract}

Keywords: religious peacebuilding; religion and violence; religion and global affairs; neoliberalism; religious literacy; critical pedagogies; conflict transformation; securitizing religion; intersectionality; religious engagement

\section{Introduction: Religion Matters, Too}

Religion can be good and bad. For too long, the field of religion and peace has repeated this argument. It is time to examine whether there are other arguments to be made. When various scholars and practitioners recognized that religion matters for politics, and especially international and global relations, they reacted to the apparent "resurgence" of religiously articulated violent ideologies. Consequently, they underscored that (and interrogated how) religion could also function constructively and positively. The key word here is "function," which denotes utility. "Utility" refers to the immediate and critical instrumental role that many religious actors, institutions, and networks play in peacebuilding, development, humanitarianism, health, education, diplomacy, and policy work around the world. The utilitarian frame points to equipping people in all professions with skills to more effectively "engage" religion. Hence, recent decades saw the emergence of a new global North discourse of "religious literacy," which complemented an extensive subfield of religion and public life (e.g., Dinham and Francis 2015). ${ }^{1}$

The field of religion and the practices of peace has grown exponentially since policy makers and analysts "discovered" religion's political relevance and world-transforming outcomes in the aftermath of the Iranian Revolution of 1979 and 11 September 2001. Those landmarks signal the conventional genealogy of the field and they coincided with or generated the publication of numerous books from Religion: The Missing Dimension of Statecraft by Johnston and Sampson (1994) to R. Scott Appleby's The Ambivalence of the Sacred: Religion, Violence, and Reconciliation (Appleby 1999) as well as his co-edited Fundamentalisms Project. ${ }^{2}$ These are just a few notable examples within an industry of other works on religion and violence, focusing mostly on the case of Islam. The "war on terror," which marked the post September 11 paradigm and the singling out of "Islamic terrorism" has shaped the study of religion, violence, and peace. It reveals the field's orientalist underpinnings. Those historical events of 1979 and 2001 shocked analysts embedded in unreconstructed secularist paradigms that failed to predict (or even perceive) 
the significance of religion for political outcomes. This shock therefore ignited research in cognate fields such as international relations (e.g., Hurd 2007; Haynes 1998; See also Lynch 2009 , 2014), leading to policy prescriptions and implementations. ${ }^{3}$ The main contribution of this line of research is to appreciate religion not only as a dependent variable or a form of false consciousness, but also as a causal power in the world. Broadly construed, I call such scholarly outputs that take religion seriously the "religion matters, too" genre.

If a growing preoccupation with religious (marked as "Islamic") violence focused on how religion can be bad, the field of religion and peace consolidated precisely as an inverse to this line of inquiry. If the "bad" religion genre sought to understand and then operationalize this understanding in order to devise containment policies and programs of securitization of Islam and Muslims globally under the auspices of the "war on terror," the "good" religion genre sought to unlock constructive and helpful heretofore-unappreciated actors within realist political thinking. Grappling with this orientalist genesis clarifies a layered continuity of the contemporary securitizing discourse, but also the constructive "global engagement with religion" turn. The latter denotes the convergence of neoliberalism and securitization policies and interpretive frames (see also Lynch 2015). To make the world safe for capital, "bad" actors needed to be securitized. "Neoliberalism," as philosopher Wendy Brown (2019) explains, is an ideology that extends a market logic to all facets of life. Within this frame, religion too becomes a capital or "soft power," a resource, to mobilize for "good," namely peace, development, and security, without necessarily interrogating the underlying structures that define their meanings. ${ }^{4}$ In addition to mobilizing "good" religion as a counter-message to combat "bad" religion, the "global engagement with religion," therefore, has also been about powerful actors such as Turkey, Saudi Arabia, and the U.S. and their leveraging of religion as a "soft power" intent on promoting powerful geopolitical interests. ${ }^{5}$ The descriptive scholarship, however, sometimes misses the complex dynamics whereby "secular" states are themselves leveraged by religious ideologues in articulating geopolitical agendas. A prominent example is the domestic sociopolitical processes that led the U.S. to relocate its embassy from Tel Aviv to Jerusalem in 2018. ${ }^{6}$ To analyze such dynamics requires an interrogation of religion and political ideology that a functionalist account of religion as a form of capital does not provide.

The intersection of neoliberalizing and securitizing religion as explicit policies and programming denotes a transition from a secularist myopia where religion did not seem to be relevant to realist concerns to a "postsecular" phase that identified religion's utility both for containing "bad" religion and for mobilizing "good" and helpful religion. ${ }^{7}$ This postsecular moment also denotes a neoliberal synergy between peace and development practices (e.g., Appleby 2015). The postsecular moment does not mean a more robust interrogation of religion and modernity, but rather a shift from a liberal register to a neoliberal one where the modernist dismissal of religion as diminishing in public significance was replaced with a framework that seeks to capitalize on it. This capitalization is where the initial insight of the field of religion and peace-namely, that religion can constitute a positive force-is coopted, thereby losing the prophetic force animating the foundational thesis of the field regarding religion's constructive contribution to peace and justice (sometimes by disturbing the peace). Indeed, the field shifted from a focus on the prophetic actor who speaks truth to power to the religious actor as a useful service provider, social influencer, and transmitter of "good" religion.

The catch is that, inherent in the argument of "religion matters, too," is the need to translate this significance into policy and action. Hence, operationalizing the field's insight (religion is essentially good and could be useful) meant that hermeneutical depth as well as contextual and historical fluency became less of a focus for scholarship about practice and more of a focus for mobilization, designed to sustain investment and promote policies. Often the "thing" that gets to be mobilized is a "correct" or "good" interpretation of faith traditions (e.g., Marshall 2013; Karam 2019). I surround correct and good with scare quotes to denote that "good" does not necessarily mean just and that any claims of correctness can serve oppressive structures, within and without religious communities. Religion and 
peace, therefore, has been a field about practice to show the effectiveness and usefulness of religion as a tool and capital rather than a substantive scrutiny of religion, violence, and justice-oriented peace. Hence, distinct from what Muslim South African liberation theologian Farid Esack calls "liberatory religion", the religion of the religion and peace field is accommodationist (Esack 1997, p. 7). Indeed, the scholarship on religion and peace has remained functionalist and descriptive in character.

While the field of religion and peace purports to study religion, seldom has it involved cross-referencing with the critical academic study of religion and the interrogation of its basic category. ${ }^{8}$ One can refer to this cross-referencing as genealogical or "archeological," pointing to how sequestering "religion" as a standalone analytic and classificatory comparative category was integral to the scaffolding of colonial modernity. The field of religion and peace brackets a consideration of the genealogies of its basic terms: "religion" (and, relatedly, the "secular") and "peace". The constructive turn, which the field of religion and peace signals, is to dispel a secularist myopic view of religion. However, this dispelling unfolded without a genealogical critique by simply evidencing repeatedly that religion is not only bad or irrelevant but also good and pertinent. By bringing in the critical lens, I do not intend to demobilize the positive meanings that people assign to their emancipation or how their religiosity may participate in this imagining of the world otherwise. The archeological register, as I show below, digs beyond utility to expose the instrumentalization of religion as yet another chapter in the history of global North hegemony (e.g., Hurd 2015), not as a newcomer to the deployment of religion as "soft" and "hard" power. The utilitarian approach is impatient with the archeological one, accusing the latter of utopianism and blindness to realist and pragmatic concerns as well as the urgency of real problems in the real world. The archeological approach dismisses the utilitarian one for its blindness to the "really real" problems hiding underneath and even enshrined in the very structures of global political discourse. My challenge has been to think through the tension between the archeological and utilitarian as generative of new horizons for religion and the praxis of justice-oriented, world transforming peace. This generative exercise retains the constructive impetus of the religion and peace field but disrupts the field's scaffoldings. Before returning to the concept of religion and peace praxis, I first sketch why research in religion and peace has been in a feedback loop, confirming (increasingly through quantitative methodologies) the same thesis that religion can be good and bad. Next, I highlight what an archaeological approach does and how it troubles the field's basic categories, opening up the field to asking new questions beyond "how can religion be more effectively contained and better mobilized?"

\section{Useful Religion Can Be Disempowering}

I identify two generations in the study of religion and peace: the liberal and neoliberal. The first generation of scholarship embraced the postsecular moment where "religion," despite a secularist myopia, "erupted" into the public and political arenas. This scholarship focused on explicitly religious leaders who, in one way or another, drew upon their religious identity and positionality to resist and transform the conditions of overt violence. This constitutes a phase of knowledge production in which exemplary or seemingly prophetic religious leaders in various contexts of explicit and acute violence were surveyed. The turn to operationalize and bureaucratize "religion" as a peacebuilding and development tool de-exceptionalize the "religious actor". Now, one's capacity to be a "religious actor" does not depend on religious virtuosity and training in religious reasoning and depth, but rather on one's capacity to mobilize members of a community whose boundaries are defined through a religious label or to promote counter messaging to combat violent religious messaging through "deradicalization" programs with such programs' persistently orientalist undertones.

The liberal phase channeled a conception of peace that was myopic of liberalism's own genealogy and the epistemological violence that created religion as a universalizable category of analysis. ${ }^{9}$ Accordingly, the discourses of multiculturalism, tolerance, and 
democracy are reproduced as unproblematic goods. The neoliberal phase of religion and peace built on the postsecular appreciation of religion's utility in diplomacy, development policy, and peacebuilding, which characterized the first liberal generation of scholarship. The neoliberal moment takes this postsecular utilitarian insight but seeks to routinize it through investing in Preventing Violent Extremism (PVE) programs and identifying "local" religious and traditional actors who can enhance other programmatic agendas (Search for Common Ground 2017). This "soft" investment accompanies the "harder" military policies of the "war on terrorism," which defined the U.S.'s wars in the post-2001 era until the pivot to a focus on China two decades later. The assumption that somehow the "religious" and "cultural" are found on the "local" level renders another category, the "international community," as supposedly the secular ("free standing" regulatory norms) binary of that "local". The archeological approach exposes the political theology, ideology, and cosmology that underpin the "international community" and its supposed technological expertise, which it can contribute to "local actors" in their development processes. The "soft" investments in religion entailed concentrated efforts to measure religion's effectiveness and utility as well as to sectoralize it and devise manuals regarding how to engage with the "religious sector" more effectively. ${ }^{10}$ Furthermore, the label "religious" in various interreligious projects such as those I surveyed during my research in Kenya and the Philippines from 2016 to 2019 often mean nothing more than communal belonging. The overall impact of this reductionism is a shallowing of both communal and religious meanings by indexing them to one another and to unidimensional narratives (see Bamat et al. 2017).

\section{Religion as Capital}

The neoliberal logic is one of "scaling up" —and one that burdens individuals to selftransform within constricted contexts that are left untouched. The operative metaphor is that of "planting a seed of peace," intended to eventually influence a social transformation one person and one intercommunal "bridging project" at a time. In my research in the global South, I entered this conversation through a close engagement with the interreligious programming of Catholic Relief Services (CRS). CRS, a transnational faith-inspired organization, has developed a sensitivity to the roles of religious actors and communities in implementing a variety of humanitarian and development/ peacebuilding agendas. The organization's focus on religious actors in peacebuilding has become a hallmark of its work in the Philippines. CRS's approach there has been disseminated to other contexts where the organization identifies similar conditions conducive to intra- and interreligious peacebuilding. Interreligious peacebuilding practices therein involve "Binding, Bonding, and Bridging" activities, or what the organization, in NGO-inflected acronymic packaging, has dubbed the "3Bs approach". "Binding" refers to intrapersonal change processes often involving the healing of trauma and the overcoming of hatred. "Bonding" moves from the intrapersonal level to the intragroup level. "Bridging" activities involve cultivating intergroup trust and relationships, which may result in positive outcomes for the "common good" and which thus might cohere with the demands of work toward "social cohesion," a key concept animating international frameworks. ${ }^{11}$

In Mindanao, the Philippines, CRS applied the 3Bs methodology mainly to facilitate the reduction of land disputes, which constitute one of the main drivers of conflict (Leguro 2017). For example, implementing the 3Bs often resulted (by design) in "solidarity" or connector projects that tangibly improved communal life. These "dialogues of action" included building a footbridge over a river for schoolchildren or devising safer methods for waste disposal. Another activity included the creation of "Zones of Peace," or Ginapalad Taka. These were created in the midst of violence and through the leadership and initiative of local communal leaders, such as Father Layson (2014), a priest who experienced his own transformation from hatred to an embrace of interreligious peacebuilding as the mission of the Catholic Church in Mindanao. The theory of change underpinning the 3Bs and multiple other programmatic foci on intergroup engagement or dialogue of action has been 
informed by an extensive body of social scientific literature loosely subsumed under the logic of the "contact hypothesis". This theory states that positive contact and relationship building across communities constitutes a preventive mechanism for violent eruptions across groups (e.g., Varshney 2002). Such research spans cases from the United States to India and likewise informs the massive industry of people-to-people peacebuilding dialogue initiatives such as CRS's. However, in practice, such a "turn to the local" became yet another kind of top-down approach, here by psychologizing the causes of violent conflict and by reducing the means by which to address them. ${ }^{12}$ In doing so, scholars and practitioners used depoliticized, natural metaphors such as "critical yeast" and "planting a seed," which denote a desirable change from a "culture of violence" to a "culture of peace" ${ }^{13}$ This invites reductive approaches to religion and the practices of peace. The "scaling" rhetoric conveys a concern with enhancing economic prosperity or the capacity to bridge vertically across status and power differentials. However, the repackaging of social capital theory (Putnam 2000) and its dissemination to local and horizontal peacebuilding in the global South reveal a focus on enhancing people's capacity to "get by" and "get along" and to transform this getting by and getting along, which elevates the concept of peace as resiliency to violence into a form of pious governance. ${ }^{14}$ What is at stake is economic and social survival based on activating identity-bridging social capital where bonding (i.e., intragroup consolidation of the "we") and binding (i.e., intrapersonal transformation) relies on reifying religion as a dominant definitional index of one's identity, a source from which one can draw and (re)write the script of the "common good". The logic underpinning such efforts posits the "public space" as a site of intergroup cooperation where individual identities are stabilized in ahistorical and hermeneutically closed claims to traditions and communal belongings.

Still, one cannot deny the measurable effectiveness, as an instrument for conflict management, of the reductive approach to social and hermeneutical scripts that construe religion as a form of social capital. For example, the implementation of the 3Bs methodology in twenty barangays in Mindanao between 2012 and 2015 resolved 35 land disputes by enhancing local capacities as well as establishing connections among municipal and governmental authorities, a network of traditional religious leaders, and the Lupong Tagapamayaoa of village pacification committees. Concurrently, 18 community-based reconciliation projects, such as the improvement of health facilities and bridge building, benefited over 21,000 people (Leguro 2017, pp. 75-78).

Since the locus of change is interpersonal relationships, where participants work on communal repair and intercommunal survival, they do not need substantive accounts of religio-cultural traditions in order to reduce a level of othering or stereotyping. They just need to get to know one another interpersonally and preferably with immediately recognized dividends. Rather than theological literacy and hermeneutical depth, what is needed is an understanding of how religion can facilitate people's resilience in the face of their present conditions. Certainly, much of the debate around people-to-people peacebuilding interrogates ways of vertically linking (scaling up) from people on the ground (horizontal relationship-building) to policies (from the "bottom" to the "top"). However, a critical account of the resiliency discourse illuminates that horizontalization, through the enhancement of people's capacity to resolve their own problems, rather than the elusive scaling itself, entrenches neoliberal rationality under the pretense of or genuine implementation of elicitive peacebuilding processes. ${ }^{15}$ Accordingly, peace or coexistence, in effect, repackages structural, cultural, and historical violence through the deployment of "bottom-up" or elicitive methodologies, whose effectiveness becomes ever more powerful because these methodologies are then imbued with religious and spiritual meanings that thrive on people's intra-subjective "conversion" from hate to friendship, love, and cooperation. Finding love and friendship in a place of prior hate and violence itself becomes a site of spiritual practice populated with claims to religious authenticity (what religious traditions are truly in their essence) as peace. This spiritualization of bottom-up, horizontal peace exposes religion's role in sustaining peace governance. Such 
governance essentially sees itself as empowering local communities to generate (elicitively) their own conflict mapping and to recover, discover, and cultivate their own ways to redress communal problems. This elicitive method is often deployed to counter any criticism that these grassroots efforts are simply colonialism in disguise. In many respects it certainly does not. People involved in facilitating elicitive methodologies would immediately underscore that they do not come to the communities with prescriptions. The elicitive mode, however, means that CRS has no way to critique a religion that perpetuates violence against women, for example, if that same religion is also useful for advancing a different peace and development agenda.

Related to the "scaling up" and "seed of peace" paradigms, the postsecular moment also signals that the "religious" has become a "sector". A prime example is Pakigdait ("peace" in Tagalog), which is an interfaith grassroots organization working in Mindanao. An affirmation of the multi-sectoral framing and its own sectoralization as an "interfaith" actor enables this organization to incorporate itself into peace governance, working with multiple investing partners, including the Asia Foundation and U.S. Agency for International Development. Together, they work on an interfaith grassroots peacebuilding program called the "Peaceconnect Project". This project was implemented in six municipalities of Lanao Del Norte. In describing the "target communities" (religious and traditional leaders, local government units, civil society organizations, security sector and non-state actors, as well as women and youth sectors) and the kind of peace work that Pakigdait enacts, especially in anticipation of the implementation of peace agreements leading to the consolidation of the Bangsamoro Autonomous Region in Muslim Mindanao (BARMM), this interfaith organization encapsulates the meaning of "interreligious peace governance". This is because it is subsidized by the turn to capitalizing on religion by the global centers of economic and political power ("the global engagement with religion") and in those global powers' attempt to make interreligious peacebuilding play a supportive role in the peace agenda. This "global engagement" requires religious actors to enact hermeneutical closures or to bracket any substantive intra- or inter-theological discourse-a point that is telegraphed in the repeated underscoring of the interfaith council that "all religions are about peace" ${ }^{16}$ Sectoralization is paradoxically disempowering, even as it empowers people and groups to act as lobbyists, coexist, cooperate with one another, and mutually overcome hate and fear.

The sectoralization of religion means that policy makers recognize the need for the selective inclusion of the "religious sector," along with "women," "youth," and so forth, in order to garner their consent, support, and supposedly specialized capacities. The sectoralization of religion, or identifying a variable named the "religious sector" to be invited to the proverbial table, may be heralded as a victory for the "religion matters, too" genre. However, the self-appointed representatives of communities, because of NGOization and global investments, are not only unelected, but also not necessarily hermeneutically fluent in the traditions they represent. Further, as a result of such postsecular efforts to bring in the "religion factor" to public discourse, one can increasingly find a class of experts and professionals populating the "global engagement with religion" discourse. The point is not to discount all of the good that such actors do, nor do I doubt that many of those populating such "interreligious" or "interfaith" intercommunal work (and those who do religion as facilitators and implementers or "data collectors" or experts about religion's effectiveness) do religion sincerely. Instead, my analysis illuminates how the postsecular sectoralization of religion depoliticizes its prophetic and emancipatory engine. Sectoralization works against a logic of social movement activism, seeking to move power and rescript public meanings.

The transition from the liberal focus on prophetic religious actors who could do good in the world and who could promote peace, through, perhaps, a reinterpretation of tradition or a disruption of the status quo, to identifying a religious sector that can enable peace and nonviolent resiliency in the face of ongoing suffering and marginalization reflects the operationalization phase of the field's basic thesis: religion can be good and bad. In its neoliberal turn, the field's main question became even narrower and fixated on practice 
rather than analysis: how can we harness good (i.e., useful) religion and contain bad religion better and more effectively? Answering this question requires less facility with the hermeneutical depth of religious traditions and political meanings and ever more fluency in ways of navigating the landscape of funding agencies, including those attached to governmental and intergovernmental bodies. What's so wrong with that? The main point is that it reflects a concern with peace, order, geopolitical agenda, and security for capital much more than with redressing wrongs. If we want to ask broader and deeper questions, we have to interrogate the basic assumptions of the field. What I mean is that the "prophet" is actually not what the "industry" of religion and peace is seeking, but rather a more domesticated "priestly" or bureaucratic figure that facilitates, often through the monitoring and evaluating mechanisms of NGOs, "keeping the peace" and communal survival rather than promoting justice. Hence, while the broader field, in its various registers, has grown in terms of volume, it has remained narrow in terms of its theory of religion, violence, and peace (Omer 2021).

\section{Feedback Loop: Two Generations, Same Thesis}

The genealogy of the first liberal generation of the religion and peace field constituted a response to the evidence of what sociologist José Casanova called "public religion" (Casanova 1994) and the mobilization along violent or nonviolent interpretations of religious sources and traditions. If Appleby recognized that the experience of the sacred can come in violent and nonviolent forms of militancy, Casanova complemented this thesis by illuminating how religion can "go public" (safely) within the rules of political liberalism, an argument for which he was critiqued by Talal Asad who demystified the "public space" as one also constructed by power (Asad 2003, p. 184). In the neoliberal phase, concepts such as the "public good" or even "inclusive societies" and "social cohesion" drive programming that seek to cultivate religious and other sectoral "buy-in". The "religious actors" here become implementers with a "local" access and especially well equipped to facilitate interreligious peace governance as I examine above. These concepts permeate policy circles as if their meanings are self-evident and as if they are not also subject to interrogation and democratic practices. Likewise, a growing neoliberal interest in how to enhance "good" religion has inundated various development and peacebuilding initiatives specializing in how to effectively promote, garner, and enhance "faith actors" and their capacity to help achieve various agendas. While still marginalized in policymaking, religion has become an area of specialization.

Peacebuilding and development work have converged (Appleby 2015). Their convergence allowed the field of religion and peace to increase an attention to social and economic conditions while the subfield of religion and development underscored the correlations between economic and other development indices and peaceful societies. Critically, peacebuilding and development policy and practice, including humanitarianism, have coalesced and interacted with one another, as evident in the UN Agenda 2030 of the 17 Sustainable Development Goals or SDGs. Goals 16, "Peace, Justice and Strong Institutions" and 17, "Partnership for the Goals," are especially pertinent to rendering religion as a "sector" to partner with "locally". This intersection of development and peace practice also clarifies the links between the fields of religion and development and religion and peace, which have operated in proximity to one another, even if the one emerged in the world of intergovernmental organizations, such as the World Bank, and the other in the academy's effort to produce public facing scholarship about religion.

What is overlooked in the literature on religion, development, and peace practice is how the understanding of "religion" with which development and policy practitioners operate leads them to categorize certain actors as useful "religious actors" (and others, presumably, as useless). It is in this utilitarian vein that an interest in women-qua-"religious actors" also emerged, with a recognition that a gender lens would disrupt the analysis of religious utility (Hayward and Marshall 2015). Some interpreters (e.g., Tomalin 2009) within the scholarly literature, which is often sponsored by the same agencies that seek 
to instrumentalize religion better (Petersen and Jones 2011), attempt to conceptually release the "religious actor" from structural (and discursive) reductionism. They do so by highlighting her agency—or her doing religion — and this problematically assumes that the "religion" such actors do can be boiled down to some kind of essence or kernel. In other words, the Jewish actor's Judaism is not a subject of analysis, only what she does in her capacity as a Jewish actor. An increased emphasis on doing rather than knowing religion and on the mere "being" of Muslim and Christian participants in various development and peacebuilding projects as sufficient to qualify them as "interreligious" may expand the scope of actors and may even bring in women and youth. However, this focus on being/doing "religion" not only reductively defines communal boundaries but it also entrenches a utilitarian rather than a normative turn in religion and peace/development.

The development/peacebuilding "synergy" (per neoliberal jargon) denotes how the prophetic impulse of the first liberal generation of the field of religion and peace was rerouted into the "seed of peace" frame of the second neoliberal generation, which means that change will happen one transformed individual at a time. The view of the individual as a locus of social transformation has animated the practice of people-to-people peacebuilding work. Similarly, integrating religion into the people-to-people frame and the neoliberal sectoralization process reflects a neoliberal capitalist logic in which the "religious" is identified as a distinct "stakeholder" whose inclusion is necessary in order to garner "local" support and "buy-in". It is through cultivating buy-in that the "religious sector" practices peace.

It is important here to interrogate the poster case of the Imam and the Pastor featured in a much-circulated film used in interreligious dialogue settings globally. ${ }^{17}$ It tells the story of how Imam Muhammad Ashafa and Pastor Wuye transformed from enemies and leaders of opposing militant groups, which were clashing in Kaduna in northern Nigeria, to partners in promoting interfaith peacebuilding efforts. We can identify key motifs: personally transforming, despite trauma and deep-seated hatred; re-approaching scripture through (ahistorical and closed hermeneutics of) proof texting to show that religions are authentically about "peace"; reaching out across identity lines and de-othering; and turning the relationship into an NGO that foregrounds "faith" or "interfaith" as its defining framework for peacebuilding and conflict transformation. This NGOization of faith locates the engine of change in intrapersonal transformation, as in the CRS's 3Bs paradigm. It also generates hermeneutically closed accounts of religions as primarily concerned with peace. This utilitarianism also reduces religion to communal boundaries and vice versa indexing unitary homogenizing stories to religious bounded identities. This forecloses the possibility of imagining the "public" space as anything other than empty of those identities and a site for intercommunal "peace" as collaboration, which is not the same as democratic praxis and virtues. These double closures (of religious and communal boundaries) operate once again to obscure an intersectional analysis of power and an imagining of alternative futures and scripts not from within the constraints of the present, but rather through critical hermeneutics.

For the field of religion and peace to chart new horizons and devise novel questions beyond how bad religion might be contained better and how good religion might be mobilized more effectively, it will need to interrogate its basic categories, namely religion and peace, scrutinize its securitizing and neoliberal logics, and undo its methodological nationalism. "Methodological nationalism" means an acceptance, as given, of geopolitical boundaries and the international map they constitute. Such methodological nationalism and internationalism are historically myopic of their own processes of becoming. Methodological nationalism in the field of religion and peace obscures religion's complicity in drawing and reproducing these boundaries through patterns of exclusion and violent ideological undercurrents (Marx 2003; Anidjar 2014). These include the "doctrine of discovery," which undergirded the colonization of lands "discovered" by the Christian west and which sanctioned the plunder, displacement, depopulation, enslavement, and extermination of peoples and lands through appeals to Christian and European supremacy, conveyed 
initially through cosmological registers and later through other "good news" discourses of civilizational progress and development (Grosfoguel 2011). The insistence of the field of religion and peace on methodological nationalism and its realist constraints has delimited its scope to documenting evidence designed to substantiate a predetermined thesis that religion can be good and bad. This is why it's important to scrutinize the genesis of religion as a comparative anthropological category in the service of imperial projects in order to understand how it is implicated in the colonial project of racial capitalism.

\section{The Archeological Lens}

Archeological tools are able to expose key assumptions of the state of the art in the study of religion and the practices of peace. These include responses to the questions: What is religion? Who is the religious actor? And what is religious action? Religion is understood primarily in terms of beliefs and a set of prescriptions regarding actions and rituals, a cognitive bias that facilitates its packaging as a message or counter-message. The cognitive bias is precisely what Asad (2003) exposed as deeply anchored in a euro- and Christian-centric, specifically Protestant, positionality. Furthermore, isolating certain kinds of action as "religious" conceals the power that defined the boundaries of the "secular" and political as distinct from the religious and cultural. This process of privatization and differentiation of the spheres is often heralded as secularization, a narrative also interpreted as the emancipation of the social and political spheres from the hegemony of religious authorities and organizing norms. A distinctively European and Christian story, the secularization of the sociopolitical spheres coincided with geopolitical colonization accompanied and undergirded by epistemic and ideological forms of colonization and erasure. The archeological tools historicize and interrogate the genealogy of "religion" and the "secular" as co-constitutive and mutually necessary for the political projects of European modernity. Hence, "religion" is not a self-evident sociological fact, but one produced by power to contain and exclude certain communities while constructing political spaces of inclusion through a discourse of nationalism or national belonging. This re-descriptive insight regarding the non-innocence of "religion" as an anthropological comparative category did not magically go away in the transition to postsecular utilitarianism. Still, even if "religion" conveys epistemological and colonial forms of violence, it has become a social fact that does work for some people whose cultural and material survival depends on "having a religion (Wenger 2009)". The tension is between the empirical realness of religion and its discursive baggage.

Let us return to Appleby's thesis in his Ambivalence of the Sacred because it has defined the "religion matters, too" genre, which makes his reliance on a Christian theological definition of religion all the more revealing of the field's positionality. His observation that religious militancy can come in both violent and nonviolent manifestations is grounded in Rudolf Otto's interpretation of the mysterium tremendum et fascinans, the holy as the "wholly other (Appleby 1999, p. 28)". The "holy" causally operates on those who experience it. For Otto, the "holy" is akin to the Kantian noumenon, beyond comprehension. At the same time, religious expressions constitute phenomena that take some characteristic shapes and forms, that is, a morphology. The phenomenological approach led Appleby to highlight profiles of a category of actors called "religious peacebuilders" (and occasionally "religious entrepreneurs") whose particular receptivity to the experience of the sacred or virtuosity credentials and consecrates them as the agents of broader social and political change. The focus on individual virtuosity or entrepreneurial capacity initially of prophetic figures and eventually just of "religious actors," writ large, to leverage religious "capital" has been pervasive in the utilitarian literature. The pervasiveness of these basic assumptions about religion exposes the Christian- and euro-centricity of the field of religion and peace and its failure to relate to critical works in the academic study of religion. This is a problem, considering the fact that "religion" is a, if not the, key category in the field of religion and peace. 
A German Lutheran theologian working in the final decades of the nineteenth century and the early decades of the twentieth century, Otto was, obviously, not omniscient, nor is the comparative category of religion innocent and self-evident. This is not a new observation. Indeed, deconstructing and historicizing comparative "religion" and the presumption of a universal and universalized definition has been at the heart of the academic study of religion as taught in religious studies departments for quite some time. What is, however, relevant for scrutiny here is why the field of religion and the practice of peace brackets this critical and archeological unearthing of its main category of analysis and practice. Under the cover of pragmatism and realpolitik, the field of religion and peace relies on a modernist/secularist definition of religion. Even when efforts are made to "deprivatize" religion and decenter secularist assumptions (e.g., Wilkinson 2020), the neoliberal fixation on utility and the subsequent subordination of "doing religion" to the demands and constraints of realpolitik drive research about religion and the practices of peace to reified (and thus likely patriarchal and heteronormative) accounts of religious traditions and (useful) religious actors. This is where the pragmatic and utilitarian logics are in tension with the archeological ones. The utilitarian push, however, is in tension with Appleby's complex account of tradition as historical, contested, and internally plural. Internal plurality, including feminist and queer (which Appleby does not discuss) accounts and reimagining of religious traditions, diminishes when the thesis that religion can be good and bad becomes codified in manuals and operationalized. The utilitarian turn, in other words, reduces the initial insight of the field to a binary grounded in a discourse of authenticity.

Let us zoom in even closer to Appleby's operative definition of religion. With Otto in the background, Appleby prioritizes religious experience as the main engine for actions deemed "religious," but also peace- or violence-promoting. Accordingly, the experience of the sacred is causal, in itself, producing violent and nonviolent militant reactions by exemplary and prophetic recipients of this encounter with the sacred. Appleby's prioritization and exceptionalization of the experience of the sacred explains why certain public actions and motivations can, indeed, be interpreted as "religious" and why subsequently religion can be understood as a potential force for good or peace and reconciliation as well as for discord and violence. The issue is not that religion is not causal in the world, but rather that Appleby, along with the many others who have replicated his basic insight, analyzes the Mysterium tremendum et fascinans as an unmediated cause. As such, it is transmitted, in the liberal phase, to (prophetic) actors who are especially receptive to this transmission and, in the neoliberal phase, to those professionalized or trained in this register to harness good and contain bad religion. This prioritizing of experience with the sacred as the engine of action deemed "religious," while itself understood historically within the specificities of political constellations and violent conflicts, presumes the sacred as an unchanged thing in and of itself. Whether through prophetic accounts of the religious actor in the liberal phase or through NGOized channels of people-to-people and scaling up rationality in the neoliberal phase, the individual constitutes the engine of religion and the practice of peace. Here, it is the experience of relationship building across communities, itself constituting a form of spiritual practice as I show above, that becomes the transformative engine, one person at a time and scaling up from there. This comes at the expense of systemic and ideological accounts of religion and violence. The archeological tools excavate and demystify simplistic interpretations of religion's causality in the world.

The causality of religion is complex and always mediated through social, political, cultural, and institutional mechanisms and secular registers. Unreconstructed and reductive cognitive approaches to religion as a "message" and a "content," which transcend specific historical complexes, as well as an equally unreconstructed devotion to "religious experiences" have skewed both the scholarly analysis of religion and peace as well as religious peace practices themselves. The cognitive reductionism enhances the utilitarian engagement with religion's "bridging" social capital and service-providing functions. Even more than a "message" to be leveraged, the utilitarian turn targets religious institutions 
and networks for their mobilizing and subcontracting capacities deemed useful within a neoliberal devolutionary and non-democratic logic.

The Asadian critique of the cognitive bias of the "public religion" discourse has generated a subfield of secularism studies, which is often interchangeable with the study of political theology. Both sites of inquiry - the theological and the secular (as a conceit, to recall William Connolly 1999)_engage in unearthing what is supposedly the really real. This archeological investigation seeks, at every instance, to expose the modern state as a violent disruption of tradition. Thus, in other writings, I argue that secularism studies and anti-modernist radical orthodoxy converge, even if traveling through different poles of the spectrum (Omer 2015). The unearthing of secularism studies and political theology seeking to demystify the "secular" and expose its true Christian and European architecture zooms in on modernity's genesis in the "wars of religion" and a critique of political liberalism (Cavanaugh 2009; Gorski and Türkmen-Dervişoğlu 2013). This line of critical scholarship intersects with more historical investigations of the comparative study of religion and its deployment in the service of nineteenth century colonial expansions (e.g., Chidester 2014), which coincided with the consolidation of nationalist projects in Europe (e.g., van der Veer 2001), the discourse of multiculturalism, and the comparative concept of "world religion (e.g., Masuzawa 2005; Wenger 2017)". A common thread in this archeological and historical demystification of religion as a comparative category is that its manufacturing was undergirded by deep-seated orientalism. The othering of Muslims and Jews constitute central facets of Christian modernity (Anidjar 2014). Some analysts, accordingly, go deeper historically to the end of the 15th century in their analysis of modernity.

Political ideology/theology were always intertwined in modernity and its twin projects of the nation-state and colonialism. The "discovery" of Turtle Island or North America in 1492 coincided with the Inquisition and its project of racialized purity before "race" was even a category of analysis (Maldonado-Torres 2014a, 2014b). The construction of the proto-Spanish nation meant a political targeting of "domestic others," Jews and Muslims, whose Jewishness and Muslimness became an essence inscribed in blood, not only interiorized belief, which ostensibly people can be converted out of, as per classical Christian supremacy. Exemplifying the constitutive dynamic of European nation-making and colonization, the Spaniards who colonized the archipelago named the Muslim inhabitants of Muslim Mindanao "Moros," referring to the Moors they had targeted back in Spain for elimination (Wenger 2017). This colonial genesis of modern religion also reveals how "religion" is deployed to define communal boundaries, regardless of the actual contexts, contents, and meanings of "religion". In framing interreligious constructs of peace as a conflict transformation tool in Mindanao of the twenty first century, the Moros are considered Muslims, as if Islam is an identity inscribed in blood, in their very being. A critical archaeological lens exposes the grammar that produced such constructs while the religion and peace field, as modeled by the 3Bs approach, simply accepts such a construct as a natural given, a methodological communalism indexed to religious affiliations where neither is open to interrogation, internal plurality, and hermeneutical openness. The racialized dimensions of the construction of religion as a comparative anthropological category are often precluded from accounts of religion and peace, which foreground the "special access" or "generic" (i.e., the "kernel" of all religions is peace) morality as its source of peace and development mobilization.

Both the "special access" to supposedly higher moral grounds and the "generic" ethical claims manifest in contemporary research (and practice) in religion and peace. The "generic" informs the utilitarian turn, which operates with an assumption that all "faith communities," when authentically displayed, have a basic and indeed "generic" commitment to peace, justice, and human dignity as well as something akin to an "overlapping consensus" in the political liberal tradition (which, of course, has its intellectual roots in theological and philosophical developments in Christian Europe). Based on this assumption regarding "good" religion, programs, gatherings, interfaith statements, and efforts 
to cooperate on "generic" moral issues, such as educating children and ending hunger, unfold and attract investment (e.g., Arigatou 2017). The "special access" to morality thesis underpins a subfield within a subfield, namely the religion and reconciliation genre, which underscores a notion of forgiveness, a deeply Christian concept as an objective of reconciliation, the likes of which ought to be identified in other religious traditions, thereby replicating the colonial and Christian-centric undertones of comparative religious studies. ${ }^{18}$ Problems arise when religious traditions assume monopoly over morality and human dignity, especially considering actual violence associated with religious histories and that marginalized people (including LGBTQI and women, of course) within religious communities are often dehumanized through religious idioms and sanctions.

The archeological/genealogical approach dismantles the special access and generic claims of the field. Saba Mahmood demonstrated how western colonial forces deployed the discourse of religious freedoms as a mechanism for Ottoman capitulation (Mahmood 2015). Elizabeth Shakman Hurd (2015) likewise showed the instrumentality of religious freedom for entrenching U.S. hegemony. These thinkers, working within and extending the framework of Asad's critique of religion, reveal the endurance of coloniality.

The invention of religion as belief, but also as blood/race, therefore, constitutes the "original sin" of the colonial moment, along with plunder, slavery, exploitation, dispossession, and genocide. As Nelson Maldonado-Torres argues, the colonial moment transitioned the discourse from an argument about true and false (with Judaism and Islam being "false" beliefs, but religions nonetheless) to a dehumanizing rendering of indigenous peoples as having no religion and therefore no soul and no humanity (Maldonado-Torres 2014b). This rendering sanctioned their displacement, exploitation, depopulation, and cultural and material genocide. Notably, some colonial missionaries did see the humanity of indigenous people and targeted them for conversion and "saving,"19 itself a practice of culturally annihilating paternalistic love (Sandoval 2000). The comparative category of religion's dehumanizing deployment, therefore, was central for the political project of colonialism. This "original sin" exposes how religion has always been a racialized (and gendered) and economically motivated category of analysis (Lugones 2008; Wynter 2003; Tuhiwai-Smith 1999; Smith 2007). To the degree that the field of religion and peace relies on reified accounts of religious traditions, religious actors, and actions, it can only remain beholden to the reductive binarism of good/bad religion.

To sum up this section, even as it pluralized in contents, contexts, and foci, the field of religion and peace has retained Christian underpinnings of what counts as religion, religious actions, and religious actors. "Christian" here denotes the entanglement of Christianity with the modern project of colonialism and exploitative racial capitalism. This is Christianity as a discourse of European empire. This imperial religion is precisely the target of Christian (and other) liberation theologies, which seek to expose and transform structural, historical, and ideological sins (e.g., Althaus-Reid 2000; Mombo 2009; Farmer 2013; Cooper 2020).

To argue that the field of religion and peace is persistently Christian- and euro-centric is simply to contend that it operates with a myopia, obscuring the genealogy of its main category of analysis, religion. The upshot is the depoliticizing impacts of interreligious peacebuilding mechanisms, under the neoliberal promises of "scaling up" and "seeds of peace". The archeological tools expose the ideological and theological conceits, but, in the process, overlook where religion and peace/development practices exceed the critical gaze, as when Nadine Bowers-Du Tois (2020) writes about decolonizing development from within African contexts that "African Independent Churches do more than serve development agendas" (p. 319). This is where the constructive upshot of the field of religion and peace can move beyond critique on the one hand and utopianism on the other.

Indeed, decolonizing the field relies on the archeological dig yet cannot remain there because peace is not a state of deconstruction or demolition but rather a state positively articulated through hermeneutical reimagining, relationship building, and democratic virtues and practices. For the field to deepen its contribution beyond a feedback loop 
endlessly confirming, with increasingly sophisticated, evidence-based research, the same "ambivalence" thesis, it needs to become intersectional. This means resisting religion's ghettoization and interrogating its genealogy as a category deployed to map and control human communities in colonized lands. While the colonial horizons closed, the same racialized logic polices the postcolonial subjects in in Euro-America. Islamophobia in Europe, for instance, is not about some sort of uncontrolled "phobia" but carries specific racializing and racist patterns.

\section{An Intersectional Lens}

Religious meanings and values can generate positive ethical accounts of political and social horizons. They are meaningful in such processes because, empirically, most of the people in the world are embedded in religious landscapes; their visions of justice cannot be divorced from them and likewise cannot be "generic". At the same time, neither the "religious" nor the "secular" are stable categories or ontologies, as some analysts have presumed (Kubálková 2003)—a presumption that others in the genealogical/archeological camp deflated. Critically, the realm of peace is a political and social one and any presumption of religion's exteriority to it (its being something other than also political) simply overlooks the hermeneutical fluidity of religious and political imaginations as well as their cross-fertilizations and enmeshments. Once again, this kind of open hermeneutics is diminished in the actual practice of religion and peace where religious and communal identities are synonymized with one another and both are analyzed as self-evident, reified, and "natural" constructs.

To recall, the field of religion and peace has sequestered "religion" as a variable of analysis in order to identify its supposedly unique causal contributions for peace (or violence). This abstraction overlooks the points of intersections between race, religion, gender, nation, class and so forth and their explanatory power to interpret religion's relation to structural, historical, cultural, epistemic, and symbolic forms of violence through an analysis of global circulations, crosscurrents, and matrices of racialization and domination. The neoliberal utilitarian abstraction, however, is not inevitable. Indeed, an intersectional prism and a genealogical sensitivity can help us connect to the field's initial normative potential and concern with social and economic justice, not only "negative peace (Galtung 1969)".

To centralize justice or structural peace will mean denaturalizing the neoliberal logic underlying peacebuilding broadly and the study of religion and peace specifically. Indeed, both "peace" (along with "development") and "religion" have violent legacies and are not at all or necessarily synonymous with justice. Advances in the field of religion and peace beyond the thesis that religion can be good and bad is to stop thinking of religion in isolation from power. Disarticulating religion from race, gender, class, nation, ethnicity, culture, historical memories, and the fashioning of religion as a "sector" entrenches power structures regulating people's lives through social disempowerment. Sectoralizing religion does not work for emancipatory social movements. The transition of the field of religion and peace into a neoliberal phase risks diminishing the field's initial appreciation of prophetic disruption and political and religious hermeneutical depth in favor of priestly actors who work within the system and who do not question its premises or the rules of the game of realpolitik. Accordingly, they are unconcerned with what liberation theologians view as global structural sins and the subsequent responsibility to redress historical and politico-economic injustices.

This is where, so long as it does not involve a critical analysis of capitalism, the religion and development/peace industry retain the imperial Christian legacy of Europe. As Thia Cooper argues, for Christian faith-based development organizations, "the poor should be helped. However, the rich did not need to change". Yet, she continues, "development cannot simply focus on improving the lives of the poor without attending to excessive wealth and power (Cooper 2020, p. 10)". Cooper's intersectional approach to Christian liberation theology exposes how, in reference to the work of religion and development, theology is co-opted, thereby concealing structural, historical, and political forms of vio- 
lence. Instead, a productivist ethic, whereby human dignity and worth is linked to humans' ability to be economically productive (see Farris 2017), permeates the faith and development industry. This theory of change links economic survival with a peaceful resilience, as I also identified in my sketch of the reductive turn from the liberal to the neoliberal phases of research in religion and peace. Hence, the utility of religion as an infrastructure of charity, humanitarianism, and services and the spirituality infused into the tasks of survival and intercommunal peacebuilding leaves the global dynamics of injustice and structural violence intact. Paolo Freire sardonically termed such philanthropic approaches "false generosity (Freire 2017, p. 44)". The convergences of peacebuilding and development also expose the fallacy of the peace such generosity affirms. Indeed, Cooper and other liberation theologians and intersectional feminist theorists confirm with clarity my argument that the field of religion and peace simply cannot accept the realities of neoliberal exploitative capitalism and their colonial roots as natural and given. In other words, to the extent that the field of religion and peace practice is not also about disrupting and rewriting the world as is in the prophetic fashion, it is indeed doomed to a reductive good/bad binarism where religion is no more than a form of "capital" to mobilize or demobilize, depending on the circumstance.

The phrase, now almost cliché, of "speaking truth to power" denotes a prophetic capacity to decolonize the common sense, denaturalize what appears natural or the ways things are. Think, for example, of slavery and its justification through biblical or purely racist ("natural") discourses. This allusion to slavery conveys that an analysis of religion and the practices of peace cannot simply focus only on how exemplary (even if flawed) people such as Mandela, Gandhi, or King acted with religious motivation and vision of truth beyond the violence structuring their lives. Their actions were also informed by interrogating the structural and ideological violence that dominated their lives, including how religious warrants and ontological claims were deployed to justify slavery, settler colonialism, and apartheid. Religion is found in both their actions and the systems they sought to transform. The utilitarian concerns of the field and its pull away from prophetic disruptions diminish the importance of systemic analyses and so does the focus on "religious experience" and individual religious actors (embedded in the "seed of peace" formula). A reliance on an unproblematized, stable, comparative category of "religion" also affirms a logic of methodological nationalism. For the field to grow beyond the truism that religion can be good and bad, it needs to sharpen its critical edges and interrogate intersectionally through a decolonial prism the power structures treated as the ways things are (neoliberal, capitalist, racialized, etc.).

\section{Conclusions: Peace Practice Versus Praxis}

Freire famously developed the concept of "praxis" as a dialectic of "reflection and action directed at the structures to be transformed (Freire 2017, p. 125)". For his critical pedagogy, it was pertinent that oppressed people gain a critical analysis of the oppressive forces structuring their condition of oppression and subjugation. Praxis is empowering people to change the very conditions of domination and violence. Rather than praxis with the intent to critically reflect about the shaping environment in order to transform it, the scholarly field of religion and peace has, for the most part, been a field about practice within the system as is. It is a field confined to realpolitik, which means the field's utilitarian and capitalist logic has propelled its traveling across a narrow road from political liberalism to neoliberal rationality. Indeed, religion, religious actors, and even religious meanings constitute a form of capital to mobilize when needed. This limitation reflects the field's continuous preoccupation with "right sizing" (Mandaville and Nozell 2017) religion's relevance to direct violence and the peace practices to counter it, to the exclusion of other forms of epistemic, cultural, symbolic, and structural violence (Springs 2015). Critically, the field of religion and peace is also susceptible to ideological, geopolitical, and theological agendas that reinsert themselves sometimes under different utilitarian or innocuous-sounding pretenses, such as the promotion of religious freedoms, development, 
and forgiveness practices. It is important to recognize when religion and peace offers a cover for ideology/theology and rearticulating hegemony and when it is truly about utility or the reduction of violence in all its forms. To recognize nefarious undertones in certain (heavily invested in) policies, such as the promotion of religious freedoms, is not the same as rendering "religious freedom" itself, along with other human rights and political norms, such as democracy, nefarious in their essence. Indeed, such rendering may be a sign of privilege and comfort only people with such freedoms can afford (see also Omer 2020).

As decolonial scholarship tells us, coloniality did not end with the processes of decolonization. Most critically, it persists epistemologically through the colonization of knowledge that informs our ability to interpret reality. Religion, as a comparative category of analysis, emerged in the context of this colonial expansion. The cutting edges of the field of religion and peace are where an analysis of religion and peace practice shifts from a reportage to praxis mode (e.g., Lynch 2020; Tarusarira 2020). If the scholarly task in the field of religion and peace does not involve asking questions beyond sketching patterns of how religion and the practice of peace within a liberal and neoliberal frame can be achieved more effectively, it is no scholarship at all, but rather research designed to sustain rather than transform the world as it is. For the field of religion and peace to advance beyond an unquestioning knowledge production-"hegemony" in Gramsci's thought-it needs to lucidly expose the architecture that confines it to realpolitik, to the art of the possible rather than to a transformative orientation toward structural and historical justice.

Funding: This research was partly funded by an Andrew Carnegie Grant received by the author.

Institutional Review Board Statement: Obtained exemption for human subject research on 12 October 2017, from the University of Notre Dame's Office of Research Compliance.

Informed Consent Statement: Not applicable.

Data Availability Statement: Not Applicable.

Acknowledgments: The intellectual and editorial support of Gladys Ganiel and Joram Tarusarira.

Conflicts of Interest: The author declares no conflict of interest.

\section{Notes}

$1 \quad$ For scholarly intervention that brings critical theoretical lenses to the study of religious literacy and the practice of religious education, see (Moore 2014). For an example of the "religion and public life" genre in its "religious literate" phase (namely engaging the political and public discourse involving religions other than Christianity), see (Bretherton 2015). This phase in the religion and public life scholarship also denotes a phase in the similar multiculturalism discourse (e.g., Kymlicka 1996). For a critically nuanced effort to revise liberal political theory, which underpins such a discussion (e.g., Laborde 2017).

2 For a description of The Fundamentalism Project, see The American Academy of Arts \& Sciences, "The Fundamentalism Project" https:/ / www.amacad.org/project/fundamentalism-project (accessed on 30 August 2021).

3 For an example of a policy prescription which had influenced the establishment of the Office of the Global Engagement with Religion in the State Department during the Obama Administration, see (Appleby and Cizik 2010). For a policy enactment of mainstreaming religion into U.S. foreign policy and strategic objectives, see the case of the International Religious Freedom Act of 1998. See for a critical engagement with this trend (Mahmood 2012).

4 The concept of "soft power" was coined by Joseph Nye (2004). In the burgeoning field of religion as soft power, see (Mandaville and Hamid 2018).

5 For an example of this genre, see (Öztürk 2021).

6 The convergences of forces and the "hard" impact of religious mobilization are clearly documented in (Zinstein 2020).

7 Jürgen Habermas is often credited with coining the concept of the "postsecular" in (Habermas 2010).

8 (Omer et al. 2015) is one exception.

9 Important nuances should be considered (e.g., Little 2015).

10 This turn in research for practitioners focuses on mobilizing "local faith actors" better (e.g., Wilkinson 2019) and on measurement of religion to ensure sustainability of investment in religion (see Vader 2015). For examples of a scholarly effort to measure religion's effectiveness in conflict reduction, see (Vüllers et al. 2015). 
For an effort to trace the consolidation of "social cohesion" as a policy agenda reflective of a growing realization that "cohesion" means a more favorable context for economic development and a way to enhance the concept's analytic precision so as to be able to measure "cohesion" better, see (Chan et al. 2006).

12 For a critical overview of the so-called local turn in peace studies, see (Paffenholz 2015).

13 For the deployment of the "critical yeast" metaphor, see (Lederach 2005). For a critique of the co-optation of "bottom up" approaches to peacebuilding, see, for example, (Lefranc 2013).

14 For the distinction between vertical (or status) and identity-based bridging, see (Wuthnow 2002).

15 John Paul Lederach is often credited with articulating the elicitive approach. Indeed, his approach has concretely influenced peacebuilding programming in Mindanao. See, for example, (Lederach 2003; Lederach 1995, pp. 55-62).

16 A consensus I gleaned from my focus group with the entire Board on July 2019, Cagayan de Oro, the Philippines.

17 For example, The Berkley Center for Religion, Peace \& World Affairs, "Film Guide: The Imam and the Pastor," June 2013, Georgetown University, https:/ / pulitzercenter.org/campus-consortium/georgetown-university-berkley-center-religion-peaceand-world-affairs (acceseed on 13 August 2021).

18 For a critical engagement, see (Tarusarira 2019).

19 Here a point of reference is the Valladolid debates between Juan Ginés Sepúlveda and Bartolomé de Las Casas (1550-51).

\section{References}

Althaus-Reid, Marcella. 2000. Liberation Theology. In The Oxford Companion to Christian Thought. Edited by Adrian Hastings, Alistair Mason and Hugh Pyper. Oxford: Oxford University Press, pp. 387-90.

Anidjar, Gil. 2014. Blood: A Critique of Christianity. New York: Columbia University Press.

Appleby, R. Scott. 1999. The Ambivalence of the Sacred: Religion, Violence, and Reconciliation. Lanham: Rowman \& Littlefield.

Appleby, R. Scott. 2015. The New Name for Peace? Religion and Development as Partners in Strategic Peacebuilding. In The Oxford Handbook of Religion, Conflict, and Peacebuilding. Edited by Atalia Omer, R. Scott Appleby and David Little. Oxford: Oxford University Press, pp. 183-211.

Appleby, R. Scott, and Richard Cizik, eds. 2010. Engaging Religious Communities Abroad: A New Imperative for U.S. Foreign Policy: Report of the Task Force on Religion and the Making of U.S. Foreign Policy. Chicago: Chicago Council on Global Affairs.

Arigatou. 2017. The Panama Declaration on Ending Violence Against Children: Global Network of Religions for Children (GNRC) Panama City, May 9-11. Available online: https://www.partner-religion-development.org/fileadmin/Dateien/News/Arigatou_ Panama_Forum/GNRC-5th-Forum-PANAMA-Declaration-on-Ending-Violence-Against-Children-Final-EN.pdf (accessed on 15 March 2019).

Asad, Talal. 2003. Formations of the Secular: Christianity, Islam, Modernity. Stanford: Stanford University Press.

Bamat, Tom, Myla Leguro, Nell Bolton, and Atalia Omer, eds. 2017. Interreligious Action for Peace: Studies in Muslim-Christian Cooperation. Baltimore: Catholic Relief Services.

Bowers-Du Tois, Nadine. 2020. Contested Development(s)? The Possible Contribution of the African Independent Churches in Decolonising Develop-ment: A South African Perspective. In African Initiated Christianity and the Decolonisation of Development: Sustainable Development in Pentecostal and Independent Churches. Edited by Philipp Öhlmann, Wilhelm Gräb and Marie-Luise Frost. London: Routledge, pp. 311-21.

Bretherton, Luke. 2015. Resurrecting Democracy: Faith, Citizenship, and the Politics of a Common Life. Cambridge: Cambridge University Press.

Brown, Wendy. 2019. In the Ruins of Neoliberalism: The Rise of Antidemocratic Politics in the West. New York: Columbia University Press. Casanova, José. 1994. Public Religions in the Modern World. Chicago: University of Chicago Press.

Cavanaugh, William. 2009. The Myth of Religious Violence: Secular Ideology and the Roots of Modern Conflict. Oxford: Oxford University Press.

Chan, Joseph, To Ho-Pong, and Elaine Chan. 2006. Reconsidering Social Cohesion: Developing a Definition and Analytical Framework for Empirical Research. Social Indicators Research 75: 273-302. [CrossRef]

Chidester, David. 2014. Empire of Religion: Imperialism and Comparative Religion. Chicago: Chicago University Press.

Connolly, William. 1999. Why I Am. Not. a Secularist. Minneapolis: University of Minnesota Press.

Cooper, Thia. 2020. A Theology of International Development. London: Routledge.

Dinham, Adam, and Matthew Francis, eds. 2015. Religious Literacy in Policy and Practice. Bristol: Bristol University Press/Policy Press.

Esack, Farid. 1997. Qur'an Liberation \& Pluralism: An. Islamic Perspective of Interreligious Solidarity Against Oppression. Oxford: Oneworld.

Farmer, Paul. 2013. Health, Healing, and Social Justice: Insights from Liberation Theology. In In the Company of the Poor: Conversations with Dr. Paul Farmer and Fr. Gustavo Gutiérrez. Edited by Michael Griffin and Jennie Weiss Block. Maryknoll: Orbis Books, pp. 35-70.

Farris, Sara. 2017. In the Name of Women's Rights: The Rise of Femonationalism. Durham: Duke University Press.

Freire, Paolo. 2017. Pedagogy of the Oppressed, 4th ed. New York: Bloomsbury.

Galtung, Johan. 1969. Violence, Peace and Peace Research. Journal of Peace Research 6: 167-91. [CrossRef] 
Gorski, Philip, and Gülay Türkmen-Dervişoğlu. 2013. Religion, Nationalism, and International Security: Creation Myths and Social Mechanisms. In The Routledge Handbook of Religion and Security. Edited by Chris Seiple, Dennis R. Hoover and Pauletta Otis. London: Routledge, pp. 136-47.

Grosfoguel, Ramón. 2011. Decolonizing Post-Colonial Studies and Paradigms of Political Economy: Transmodernity, Decolonial Thinking, and Global Coloniality. Transmodernity: Journal of Peripheral Cultural Production of the Luso-Hispanic World 1: 1-38. [CrossRef]

Habermas, Jürgen. 2010. An. Awareness of What Is Missing: Faith and Reason in a Post-Secular Age. Cambridge: Polity.

Haynes, Jeff. 1998. Religion in Global Politics. London: Longman.

Hayward, Susan, and Katherine Marshall, eds. 2015. Women, Religion, and Peacebuilding: Illuminating the Unseen; Washington, DC: U.S. Institute of Peace Press.

Hurd, Shakman Elizabeth. 2007. The Politics of Secularism in International Relations. Princeton: Princeton University Press.

Hurd, Elizabeth Shakman. 2015. Beyond Religious Freedom. Princeton: Princeton University Press.

Johnston, Douglas, and Cynthia Sampson, eds. 1994. Religion, The Missing Dimension of Statecraft. Oxford: Oxford University Press.

Karam, Azza. 2019. Religion and Sustainable Development: The Journey from Why to Engage to a Plea for Caution. Inaugural lecture for her chair at the University of Amsterdam. June 13. Available online: https:/ /www.godgeleerdheid.vu.nl/en/Images/ Inaugural_Lecture_Azza_Karam_tcm239-918580.pdf (accessed on 13 August 2021).

Kubálková, Vendulka. 2003. Toward an International Political Theology. In Religion in International Relations: The Return from Exile. Edited by Fabio Petito and Pavlos Hatzopoulos. New York: Palgrave, pp. 79-105.

Kymlicka, Will. 1996. Multicultural Citizenship: A Liberal Theory of Minority Rights. Oxford: Oxford University Press.

Laborde, Cécile. 2017. Liberalism's Religion. Cambridge: Harvard University Press.

Layson, Bert. 2014. The Search for the Common Good: Story of the Church in Pikit. Paper presented at the ASEACCU Conference at Ateneo De Davao University, Manila, Philippines, August 28-30.

Lederach, John Paul. 1995. Preparing for Peace: Conflict Transformation Across Cultures. Syracuse: Syracuse University Press.

Lederach, John Paul. 2003. Little Book of Conflict Transformation: Clear Articulation of the Guiding Principles by a Pioneer in the Field. New York: Good Books.

Lederach, John Paul. 2005. The Moral Imagination: The Art and Soul of Building Peace. Oxford: Oxford University Press.

Lefranc, Sandrice. 2013. A Critique of ‘Bottom-Up' Peacebuilding: Do Peaceful Individuals Make Peaceful Societies? In Peacebuilding, Memory, and Reconciliation: Bridging Top.-Down and Bottom-Up Approaches. Edited by Bruno Charbonneau and Geneviève Parent. New York: Routledge, pp. 34-52.

Leguro, Myla. 2017. The A3Bs Project Team. Mindanao: Binding, Bonding and Bridging. In Interreligious Action for Peace: Studies in Muslim-Christian Cooperation. Edited by Tom Bamat, Myla Leguro, Nell Bolton and Atalia Omer. Baltimore: Catholic Relief Services, pp. 71-82.

Little, David. 2015. Religion, Peace, and the Origins of Nationalism. In The Oxford Handbook of Religion, Conflict, and Peacebuilding. Edited by Atalia Omer, R. Scott Appleby and David Little. Oxford: Oxford University Press, pp. 61-99.

Lugones, Maria. 2008. The Coloniality of Gender. Worlds \& Knowledges Otherwise 2: 1-17.

Lynch, Cecelia. 2009. A Neo-Weberian Approach to Religion in International Politics. International Theory 1: 381-408. [CrossRef]

Lynch, Cecelia. 2014. A Neo-Weberian Approach to Studying Religion and Violence. Millennium: Journal of International Studies 43: 273-90. [CrossRef]

Lynch, Cecelia. 2015. Religious Communities and Possibilities for "Justpeace". In The Oxford Handbook of Religion, Conflict, and Peacebuilding. Edited by Atalia Omer, R. Scott Appleby and David Little. New York: Oxford University Press, pp. 597-612.

Lynch, Cecelia. 2020. Wrestling with God: Ethical Precarity in Christianity and International Relations. Cambridge: Cambridge University Press.

Mahmood, Saba. 2012. Religious Freedom, the Minority Question, and Geopolitics in the Middle East. Comparative Studies in Society and History 54: 418-46. [CrossRef]

Mahmood, Saba. 2015. Religious Difference in a Secular Age: A Minority Report. Princeton: Princeton University Press.

Maldonado-Torres, Nelson. 2014a. AAR Centennial Roundtable: Religion, Conquest, and Race in the Foundations of the Modern/Colonial World. Journal of the American Academy of Religion 82: 636-65. [CrossRef]

Maldonado-Torres, Nelson. 2014b. Race, Religion, and Ethics in the Modern/Colonial World. Journal of Religious Ethics 42: 691-711. [CrossRef]

Mandaville, Peter, and Shadi Hamid. 2018. The Rise of Islamic Soft Power: Religion and Foreign Policy in the Muslim World. Foreign Affairs. December 7. Available online: https:/ / www.foreignaffairs.com/articles/middle-east/2018-12-07/rise-islamic-soft-power (accessed on 30 November 2021).

Mandaville, Peter, and Melissa Nozell. 2017. Engaging Religion and Religious Actors in Countering Violent Extremism. United States Institute of Peace Special Report 41. August 3. Available online: https:/ / www.usip.org/sites/default/files/SR413-EngagingReligion-and-Religious-Actors-in-Countering-Violent-Extremism.pdf (accessed on 30 November 2021).

Marshall, Katherine. 2013. Global Institutions of Religion: Ancient Movers, Modern Shakers. London: Routledge.

Marx, Anthony. 2003. Faith in Nation. Oxford: Oxford University Press.

Masuzawa, Tomoko. 2005. The Invention of World Religions: Or, How European Universalism Was Preserved in the Language of Pluralism. Chicago: University of Chicago Press. 
Mombo, Esther. 2009. Religion and Materiality: The Case of Poverty Alleviation. In Religion and Poverty: Pan-African Perspectives. Edited by Peter Paris. Durham: Duke University Press, pp. 213-27.

Moore, Diane L. 2014. Overcoming Religious Illiteracy: Expanding the Boundaries of Religious Education. Religious Education 109: 379-89. [CrossRef]

Nye, Joseph. 2004. Soft Power: The Means to Success in World Politics. New York: Public Affairs.

Omer, Atalia. 2015. Modernists Despite Themselves: The Phenomenology of the Secular and the Limits of Critique as an Instrument of Change. Journal of the American Academy of Religion 83: 27-71. [CrossRef]

Omer, Atalia. 2020. Decolonizing Religion and the Practice of Peace: Two Case Studies from the Postcolonial World. Critical Research on Religion 8: 273-96. [CrossRef]

Omer, Atalia. 2021. Domestic Religion: Why Interreligious Dialogue in Kenya Conserves Rather than Disrupts Power. In A Requiem for Peacebuilding? Edited by Jorg Kustermans, Tom Sauer and Barbara Segaert. London: Palgrave Macmillan, pp. 59-96.

Omer, Atalia, R. Scott Appleby, and David Little, eds. 2015. The Oxford Handbook of Religion, Conflict, and Peacebuilding. Oxford: Oxford University Press.

Öztürk Erdi Ahmet. 2021. Religion, Identity and Power: Turkey and the Balkans in the Twenty-First Century. Edinburgh: Edinburgh University Press.

Paffenholz, Thania. 2015. Unpacking the Local Turn in Peacebuilding: A Critical Assessment towards an Agenda for Future Research. Third World Quarterly 36: 857-74. [CrossRef]

Petersen, Marie Juul, and Ben Jones. 2011. “Instrumental, Narrow, Normative?” Reviewing Recent Work on Religion and Development. Third World Quarterly 32: 1291-306.

Putnam, Robert D. 2000. Bowling Alone: The Collapse and Revival of American Community. New York: Simon \& Schuster.

Sandoval, Chela. 2000. Methodology of the Oppressed. Minneapolis: University of Minnesota Press.

Search for Common Ground. 2017. Transforming Violent Extremism: A Peacebuilder's Guide. Available online: https://www.sfcg. org/wp-content/uploads/2017/04/SFCG-Peacebuilders-Guide-to-Transforming-VE-final.pdf (accessed on 15 August 2021).

Smith, Andrea Lee. 2007. Heteropatriarchy and the Three Pillars of Settler Colonialism. In The Color. of Violence: The INCITE! Anthology. Edited by Andrea Lee Smith, Ben E. Richie, Julian Sudbury and Janelle White. Cambridge: South End Press, pp. 68-73.

Springs, Jason A. 2015. Structural and Cultural Violence in Religion and Peacebuilding. In The Oxford Handbook of Religion, Conflict, and Peacebuilding. Edited by Atalia Omer, R. Scott Appleby and David Little. Oxford: Oxford University Press, pp. 146-79.

Tarusarira, Joram. 2019. The Anatomy of Apology and Forgiveness: Towards Transformative Apology and Forgiveness. International Journal of Transnational Justice 13: 206-24. [CrossRef]

Tarusarira, Joram. 2020. Religion and Coloniality in Diplomacy. The Review of Faith E International Affairs 18: 87-96.

Tomalin, Emma. 2009. Buddhist Feminist Transnational Networks, Female Ordination and Women's Empowerment. Oxford Development Studies 37: 81-100. [CrossRef]

Tuhiwai-Smith, Linda. 1999. Decolonizing Methodologies: Research and Indigenous Peoples. London: Zed Books.

Vader, Jennie. 2015. Collaborative Learning Projects (CDA): Meta-Review of Inter--Religious Peacebuilding Program. Evaluations. Peacebuilding Evaluation Consortium for CDA Collaborative Learning Projects made possible by Carnegie Corporation of New York. June. Available online: https://www.cdacollaborative.org/wp-content/uploads/2016/01/Meta-Review-of-Inter-ReligiousPeacebuilding-Program-Evaluations.pdf (accessed on 2 August 2021).

van der Veer, Peter. 2001. Imperial Encounters: Religion and Modernity in India and Britain. Princeton: Princeton University Press.

Varshney, Ashutosh. 2002. Ethnic Conflict and Civic Life: Hindus and Muslims in India. New Haven: Yale University Press.

Vüllers, Johannes, Birte Pfeiffer, and Matthias Basedau. 2015. Measuring the Ambivalence of Religion: Introducing the Religion and Conflict in Developing Countries (RCDC) Dataset. International Interactions: Empirical and Theoretical Research in International Relations 41: 857-81. [CrossRef]

Wenger, Tisa. 2009. We Have a Religion: The 1920s Pueblo Indian Dance Controversy and American Religious Freedom. Chapel Hill: University of North Carolina Press.

Wenger, Tisa. 2017. Religious Freedom: The Contested History of an American Ideal. Chapel Hill: University of North Carolina Press.

Wilkinson, Olivia. 2019. Partnering with Local Faith Actors to Support. Peaceful and Inclusive Societies. Washington and Bonn: Joint Learning Initiative on Faith \& Local Communities and International Partnership on Religion and Sustainable Development, Available online: https:/ /jliflc.com/resources/peace-sdg-16-pard/ (accessed on 15 August 2021).

Wilkinson, Olivia. 2020. Secular and Religious Dynamics in Humanitarian Response. London: Routledge.

Wuthnow, Robert. 2002. Religious Involvement and Status-Bridging Social Capital. Journal for the Scientific Study of Religion 41: 669-84. [CrossRef]

Wynter, Sylvia. 2003. Unsettling the Coloniality of Being/Power/Truth/Freedom: Towards the Human, After Man, Its OverrepresentationAn Argument. The New Centennial Review 3: 257-337. [CrossRef]

Zinstein, Maya dir. 2020. Till Kingdom Come. London: Metfilms. 